\title{
OBSERVATIONS ON CHYTRIDIACEOUS PARASITES OF PHANEROGAMS. XX. RESTING SPORE GERMINATION AND EPIBIOTIC STAGE OF PHYSODERMA BUTOMI SCHROETER ${ }^{1}$
}

\author{
F. K. Sparrow \\ Department of Botany, University of Michigan, Ann Arbor 48104
}

A B S T R A C T

The development and morphology of Physoderma butomi Schroeter on Butomus umbellatus L., found in Michigan, is followed from germination of the resting spore through formation of epibiotic and endobiotic stages, to resting spore. No evidence for sexuality was found.

Physoderma BUtomi Schroet., is obligately parasitic on the beautiful European emergent aquatic Butomus umbellatus $\mathrm{L}$. and is of particular interest to students of zoosporic Phycomycetes since it was in this species that de Bary's student Büsgen (1887) discovered the epibiotic stage of this otherwise wholly endobiotic fungus. The earliest collection of the species by Schroeter is labelled "Protomyces punctiformis, coll. 12.8. 73" near Rastatt. It was later (1883) named Physoderma butomi $\mathrm{n}$. sp. but not described by him. It is evident from notes in Schroeter's collections that Krieger sent unnamed infected material of Butomus to Schroeter, collected at Königstein. The latter identified it with his own species and probably furnished the description issued by Krieger on Packet No. 545 of "Fungi saxonici." The binomial should perhaps read Physoderma butomi Schroeter apud Krieger. Büsgen's material was from the Botanical Garden of the University of Strasbourg where the synoptic collection still (1971) contains Butomus, but now without the infection.

Materials AND METHods-The present material was collected at Square Lake, Oakland County, Michigan, October, 1972. This site was reported in a previous paper (Sparrow, 1956). At the same time seeds were collected and both these and fungus-infected leaves were stored in a refrigerator at $0 \mathrm{C}$. In March of 1973 both seeds and resting spores were left in petri dishes of Square Lake water at $20 \mathrm{C}$ under intermittant 12 $\mathrm{ft}$-c of fluorescent light. Under these conditions they germinated readily.

${ }^{1}$ Received for publication 18 April 1973.

Assisted by N.S.F. Grant GB 3333. I wish to thank Dr. Aniela Krawiecowa, Head, Department of Plant Systematics, Herbarium Inst. Bot. Univ. Wratislaviensis for loan of Schroeter's specimens. The de Bary collection of slides in British Museum (N.H.) has one slide, "Dauersporen Building F. '86," of what is probably Büsgen's material. I wish to thank the Keeper of Botany for permission to examine this.

Figures inked by Elvira Shappirio.
RESTING SPORES AND THEIR GERMINATIONLike nearly all other species of Physoderma, the resting spores occur in dark flecks or pustules on the leaves and inflorescence stalks. They are broadly ellipsoidal and slightly flattened on one face (Fig. 1). The wall is relatively thin (about $2 \mu \mathrm{m}$ ) and amber-colored when not obscured by nearly black host cell residue. The contents are disposed in the highly characteristic manner of a Physoderma, i.e., with a large, somewhat eccentric central vacuole surrounded by small, bright, fattyappearing globules (Fig. 1). Mature spores are $20-32 \mu \mathrm{m} \times 13-30 \mu \mathrm{m}$. One to five may be present in a usually subepidermal host cell within which all traces, save for an occasional coarse element of the vegetative system have disappeared. Rarely, epidermal cells bear them.

The process of germination was well described by Büsgen and does not differ in essentials from that reported in other species of the genus. Suffice to say, a broad lid is dehisced circumscissiley from the flattened face of the spore (Fig. 2, 4, 5) and is pushed backwards or upwards by the steady elongation of a tapering, broad, finger-like, socalled "endosporangium" (Fig. 2, 3). The latter structure, after attaining a length of $20-25 \mu \mathrm{m}$, forms apically a broad clear discharge papilla (Fig. 4). Meanwhile, the contents undergo a series of changes which result in 30-40 discrete colorless refractive globules being equally spaced in the finely granular cytoplasm (Fig. 6). These are the globules of the zoospores around each of which a zoospore 6-7 $\mu \mathrm{m}$ in diam will be cleaved from the cytoplasm.

Populations of resting spores randomly germinate as described above. At the moment of discharge of the zoospores the conspicuous apical papilla will suddenly "blow out" (Fig. 7) accompanied by the zoospores which outside remain for a moment imbedded in the "slime" of the papilla. They then assume individual motility by a flexing of their single posterior $20-25 \mu \mathrm{m}$ long flagellum, and dart away (Fig. 8). Laggard spores often undergo amoeboid changes of shape during and 

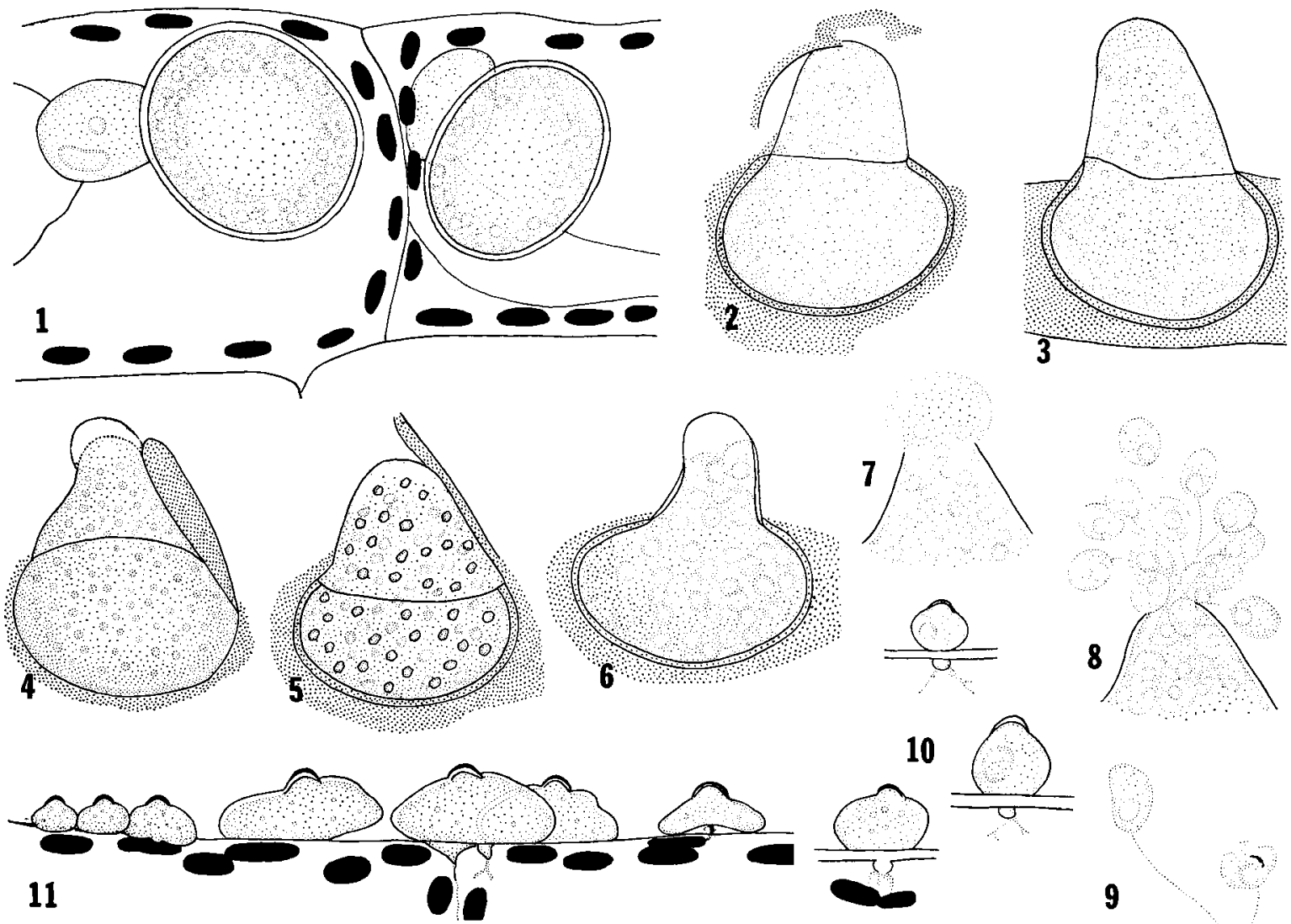

9
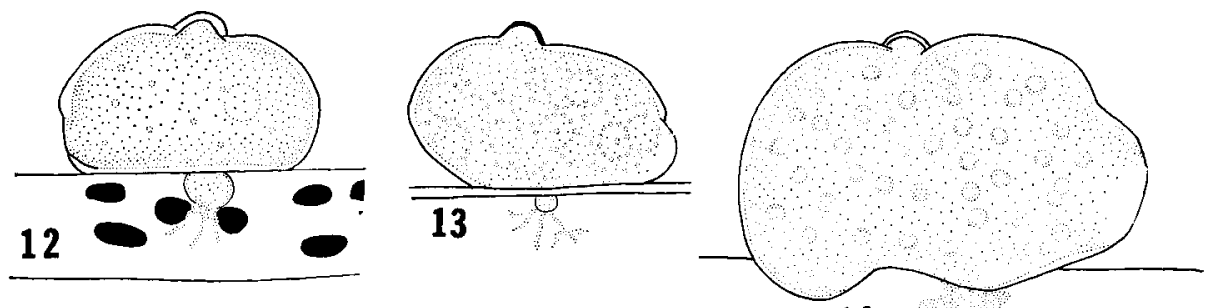

14
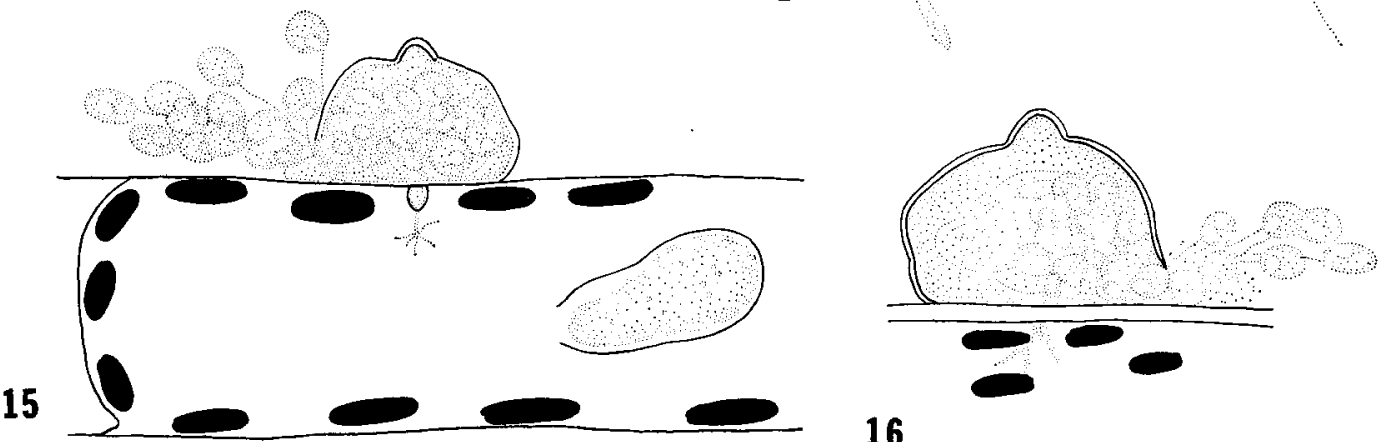

16

Fig. 1-16. 1. Butomus umbellatus cells with mature resting spores. A turbinate cell attends each spore. 2. Germinating resting spore with dehisced cap of wall and host material thrown back by enlarging endosporangium. 3-5. Later stages, showing changes in contents and papilla formation. 6. Mature endosporangium with conspicuous discharge papilla. 7, 8. Stages in discharge of posteriorly uniflagellate zoospores. 9. Zoospores from resting spores; two with arc of material visible. 10. Three very young epibiotic thalli formed from r. s. zoospores. All show remains of apical unexpanded portion of encysted zoospore. 11. Excised portion of host, bearing a series of epibiotic sporangia in varying stages of development. Youngest at left and extreme right. This and Fig. 17 serve 
after moving out of the sporangium, at which time, in addition to the somewhat basal globule with a diam of $2.5 \mu \mathrm{m}$, a dark crescent-like body (nuclear cap?) is clearly visible (Fig. 9). Precise duration of movement is not known, but the even gliding with changes of direction of the ovoid spore may continue for at least $2 \mathrm{hr}$ before it comes to rest and encysts.

EPIBIOTIC PHASE-Zoospores produced by resting spores ("r. s. zoospores") settle down and encyst in remarkably large numbers on seedlings of Butomus introduced into the water in which they are swimming (Fig. 17). Here, they undergo loss of flagellum, apparently by retraction into the body, and produce a delicate infection tube. If the epibiotic stage is to be produced, as it is early in exposure of seedlings to zoospores, the tip of the discharge tube forms an endobiotic, stubby, bushy, rhizoidal system within the host, which arises usually from a minute apophysis (Fig. 10). Early in the subsequent enlargement of the epibiotic cyst it is evident that a dorsal cap of cyst wall remains rigid and unenlarged as the remainder of the body expands laterally and to a lesser degree upwards (Fig. 10). Continued growth in this manner results in the formation at maturity of a somewhat broader than high epibiotic structure with a wavy or crenulated outline and an apical cap which is the unexpanded or only slightly expanded distal part of the original zoospore cyst (Fig. 10, 11). Final maturation of this whole body - the "ephemeral" or "epibiotic" sporangium-involves a series of successive changes much like that in the endosporangium, with a number of equally spaced, like-sized, usually colorless globules (Fig. 12-14). Rarely, these globules are orange-colored. During changes in the cytoplasm a broad basal papilla has been formed on the sporangium (Fig. 13, 14, right hand, base). Great variation in size and number of zoospores is found among these sporangia, undoubtedly determined by the amount of nourishment available. Such sporangia range from 10$20 \mu \mathrm{m}$ high $\times 22-35 \mu \mathrm{m}$ wide (av. 50). Although they may be present in great numbers on a seedling, (Fig. 17) if they do any harm to individual cells it cannot be detected in the organization and color of the host cell contents.

At the moment of discharge of epibiotic sporangia, the single basal papilla instantly swells up and dissolves in the medium, and the 20-30 zoospores are forcefully ejected from the sporangium through the $3-5 \mu \mathrm{m}$ in diam orifice (Fig. 15, 16). Zoospores are slightly smaller ( $3-5 \mu \mathrm{m}$ in diam) than those from resting spores and have a smaller $(1.5 \mu \mathrm{m})$ colorless (rarely orange-colored) globule and $20 \mu \mathrm{m}$ long posterior flagellum (Fig. 18). No fusions of these zoospores were seen and it was observed that they could give rise to new epibiotic sporangia. Furthermore, epibiotic sporangia were capable of repeated internal proliferation (Fig. 19-22).

ENDOBIOTIC STAGE-In seedlings this stage did not appear in water cultures until the 9th day after their exposure to resting spore zoospores. Prior to that, the epibiotic stage was found rapidly multiplying itself (Fig. 17). The encysted resting zoospore ("r. s. zoospore") produced at the tip of its penetration tube inside the host cell a primary turbinate cell (Fig. 23a). This early stage was difficult to detect, but enough examples were found to confirm Büsgen's findings. Transverse segmentation of this cell usually occurred, and a rhizoid of variable length emerged often from the basal cell, at the tip of which a new turbinate cell was formed. The latter in turn divided, produced a rhizoid which penetrated into the parenchyma tissue, and replicated the young thallus which by this means "wandered from cell to cell." (Fig. 23) Such turbinate cells were somewhat broadly ovate, 6$15 \mu \mathrm{m} \times 3-9 \mu \mathrm{m}$, and once to occasionally twice transversely septate (Fig. 24). The walls were evidently very delicate, and frequently one or both cells were found collapsed. Very little if any change in the disposition of host cell contents occurred during this growth. Brown areas on seedlings were found after 2 weeks and these were due to the production of resting spores. The process was also followed in tissue of mature Butomus plants inoculated in tubs of water by adding 1972collected resting spores. Here, however, such development could only be followed in detail where it was occurring in clear epidermal cells.

Development of the resting spore was the same in seedlings as in mature plant tissue. A lateral outgrowth of varying length, usually short, from one end of a turbinate cell produced at its tip a globular swelling (Fig. 25a). This continued to enlarge and eventually became the relatively huge rudiment of the resting spore (Fig. 24). When maximum size was attained, a wall was laid down around it. Meanwhile, during growth of this large object the host cell contents became disorganized,

$\leftarrow$

also to illustrate the density of sporangia formed on host parts where large numbers of resting zoospores are present in medium. 12, 13. Nearly mature epibiotic sporangia show apophysate endobiotic stubby rhizoids in host cell. Discharge papilla formed at right, lowermost lobe. 14. Mature sporangium with basal papilla; rhizoids covered by host debris. 15. Discharging epibiotic sporangium; to right is an epibiotic sporangium being renewed by internal proliferation. 16. Another discharging sporganium. All $\times 1100$. 


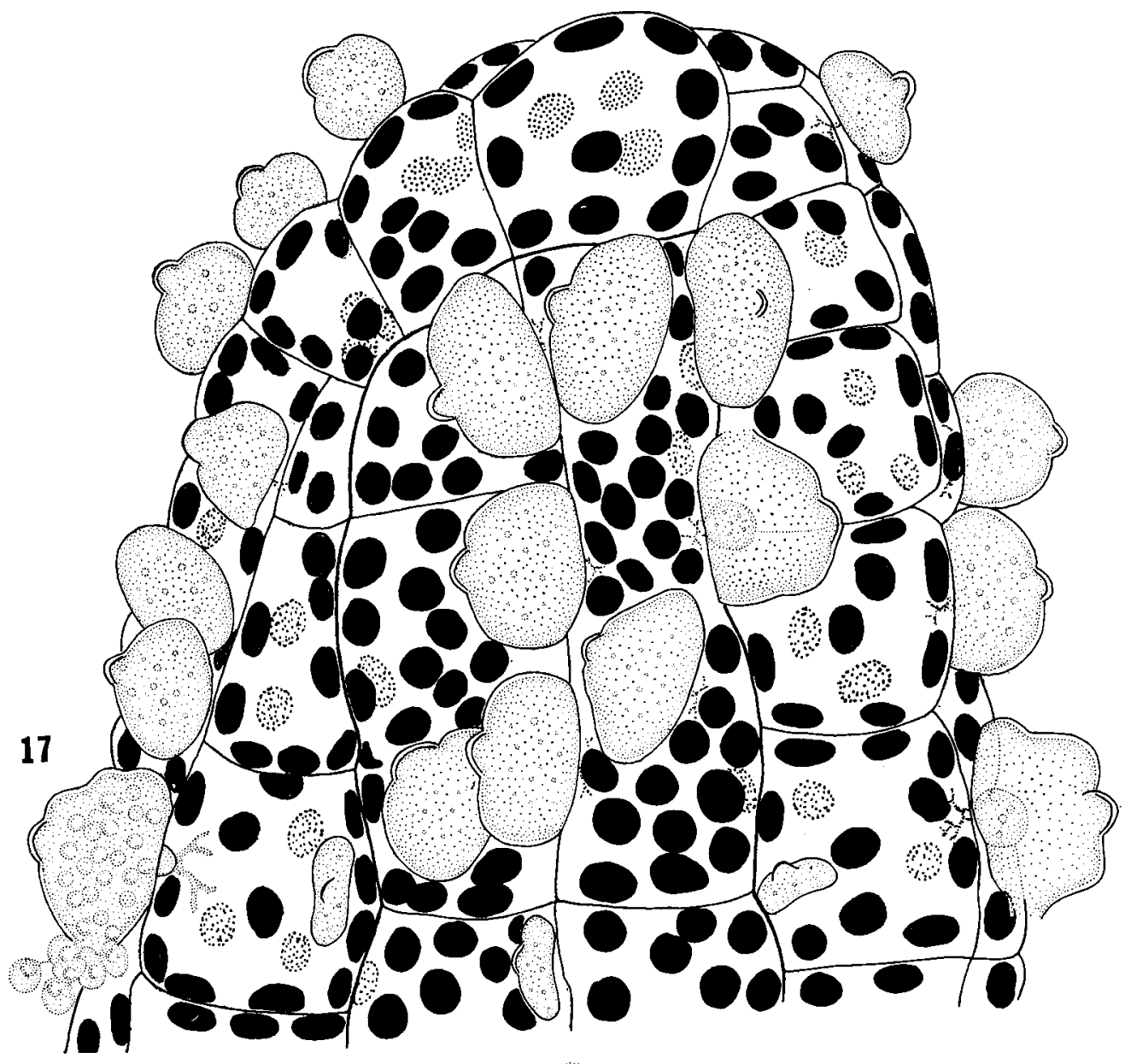

19
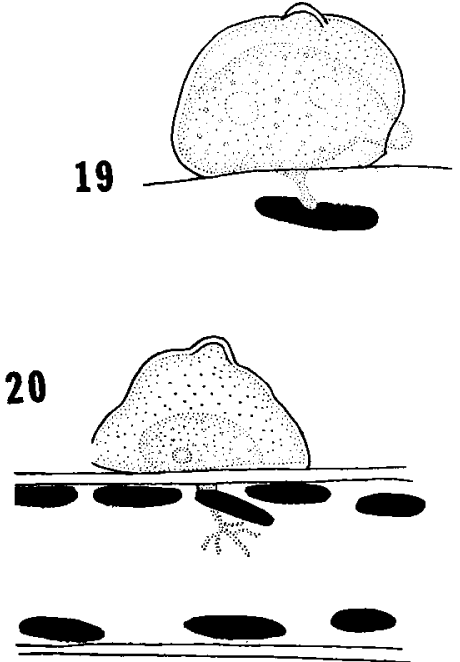

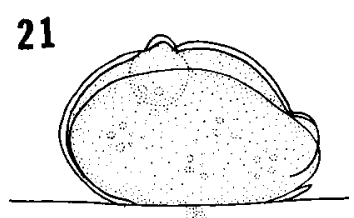

18
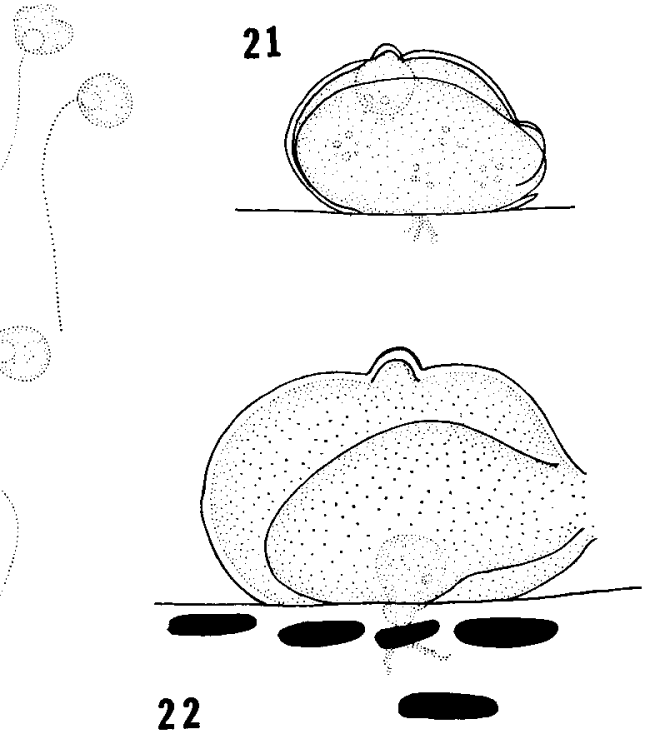

Fig. 17-22. 17. Tip of young seedling of Butomus bearing numerous epibiotic sporangia in all stages of developFig. 17-22. 17. Tip of young seedling of Butomus bearing numerous epibiotic sporangia in all stages of de populations of ment, again illustrative of the great nuorly uniflagellate zoospores of epibiotic stage. 19-22. Sporangia being renewed by internal proliferation. All $\times 1100$. 

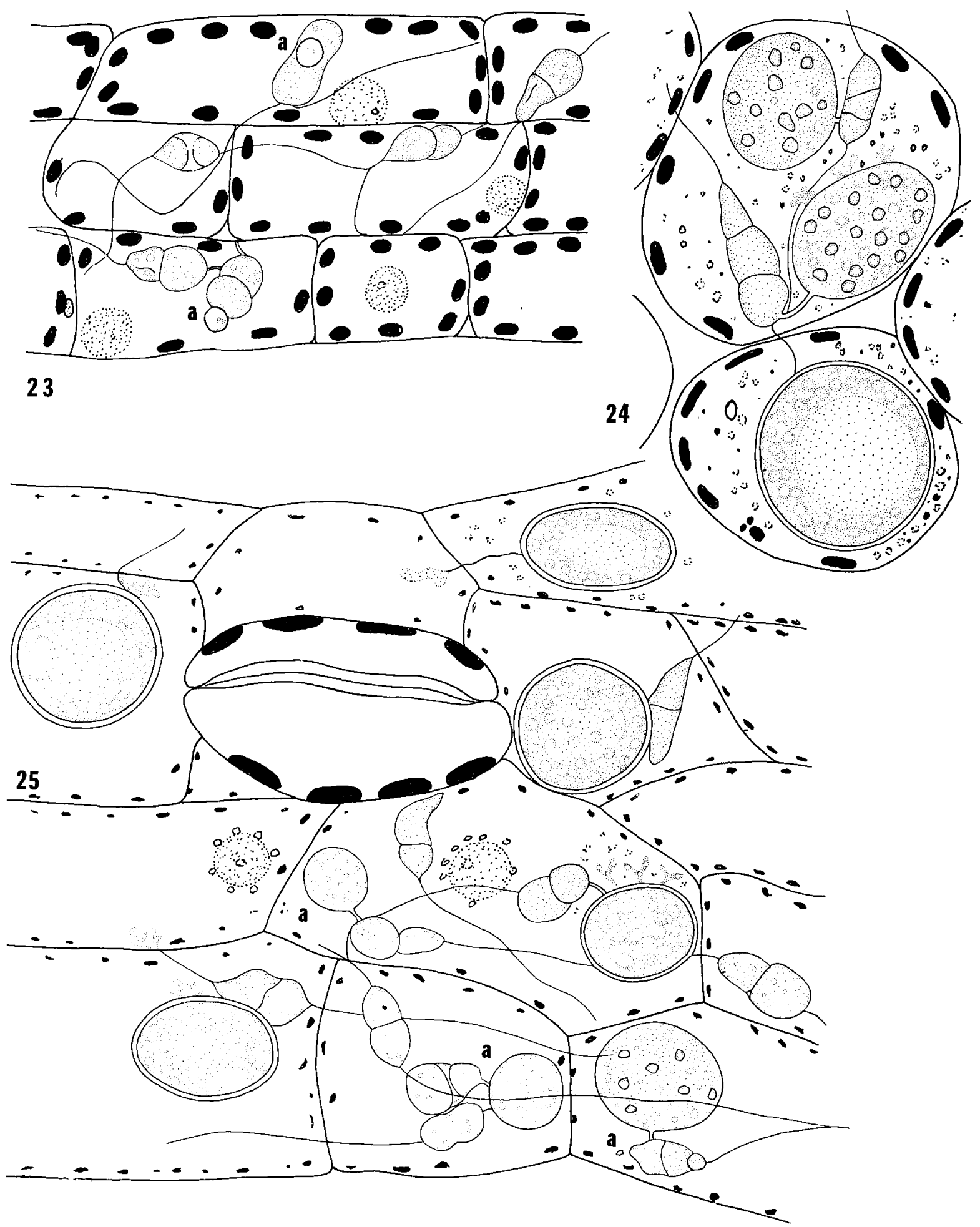

Fig. 23-25. 23. Young stages in development of endobiotic polycentric thallus. At "a" are seen the epibiotic cysts of the infecting zoospores and beneath them the primary turbinate cells. 24. Subepidermal cells of Butomus bearing immature resting spores with antler-like outgrowths, attendant three-celled turbinate cells and mature resting spores. 25. Epidermal cells of mature leaf showing at "a" young resting spores arising from tips of outgrowths from turbinate cells, and $r$. sp. with outgrowths. All $\times 1100$. 
and it is possible that the resting spore rudiment was functioning as might an independent thallus of an Olpidium in a host cell, i.e., apparently absorbing food over its whole surface. Such prodigious growth could not be imagined to occur by reason of the activities of the feeble rhizoidal system alone. Various changes of spore contents occurred during maturation. The wall thickened to about $2 \mu \mathrm{m}$, became amber-colored, and the contents assumed the characteristic disposition and size earlier mentioned. Often, but not always, delicate antler-like outgrowths were found on developing resting spores (Fig. 24, 25).

In mature host parts heavy concentrations of resting spores occurred, primarily in subepidermal tissue. The dense host debris which collected around these spores in mature or older parts of the infection made observation of details impossible. As indicated, only in younger areas of infection and in epidermal tissue and in seedlings could details of fungus structure be observed.

Discussion-One cannot refrain from paying tribute to that "graduate student" of long ago, Büsgen, who so accurately described this fungus. True, details were lacking which have been supplied here, primarily in the epibiotic stage, but the main features, including discovery of this epibiotic stage for the first time in a Physoderma were laid down nearly 90 years ago. Since then, the fungus has not been critically studied.

Morphologically, there is nothing distinctive exhibited by this Physoderma. Its epibiotic stage resembles that found on the umbellifer Sium suave and on Caltha palustris (Sparrow and Johns, 1959). Its turbinate cells are like those of a number of species in shape, size, and number of cells and differ only in being prone to collapse readily, a feature well brought out in Büsgen's figures. Resting spore size is not distinctive. Data derived from cross-inoculation experiments will be needed to identify the host range of the Butomus parasite and to ascertain its distinctiveness as a taxon, and this we hope to do.

\section{LITERATURE CITED}

Büsgen, M. 1887. Beitrag zur Kenntnis der Cladochytrien. Beitr. Biol. Pflanz. 4:269-283.

SCHROETER, J. 1883. Untersuchungen der Pilzgattung Physoderma. Jahresber. Schles. Gesell. Vaterland. Cultur. 60: 198-200. 1882.

SParrow, F. K. 1956. Observations on chytridiaceous parasites of phanerogams. V. The occurrence of Physoderma butomi and $P$. vagans in the United States. Mycologia 48: 765-766. , AND R. M. JoHNs. 1959. Observations on chytridiaceous parasites of phanerogams. IX. Epibiotic sporangial stages of Physoderma collected in the field. Arch. Mikrobiol. 34: 93-102. 